\title{
Editorial: Where to Raise Happy and Skilled Children: How Environment Shapes Human Development and Education
}

\author{
Sabine Pirchio ${ }^{1 *}$, Blanca Silvia Fraijo Sing $^{2}$ and Ylenia Passiatore ${ }^{3}$ \\ ${ }^{1}$ Department of Dynamic and Clinical Psychology, Sapienza University of Rome, Rome, Italy, ${ }^{2}$ Department of Psychology and \\ Communication Sciences, University of Sonora, Hermosillo, Mexico, ${ }^{3}$ Department of Education, Roma Tre University, \\ Rome, Italy
}

Keywords: development, education, environment, child, adolescent, relationships, school

\section{Editorial on the Research Topic}

Where to Raise Happy and Skilled Children: How Environment Shapes Human Development and Education

Child development consists of a series of changes that occur in the individual, driven by genetic, biological, social, cultural, and environmental resources and constraints (Bronfenbrenner, 1979; Hendry and Kloep, 2002). Child development has been described and explained through different perspectives, focusing on the changes in different components (e.g., cognition, emotion, relations, language, etc.) implying different developmental processes (e.g., continuous vs. discontinuous, quantitative vs. qualitative, maturational vs. social processes) and using different scientific methodologies (e.g., lab experiments, field observations, cross-sectional vs. longitudinal research designs).

This long research tradition has helped uncover the many ways in which a newborn grows into

Edited and reviewed by: Silvia Collado, University of Zaragoza, Spain

*Correspondence: Sabine Pirchio sabine.pirchio@uniroma1.it

Specialty section

This article was submitted to

Environmental Psychology, a section of the journal

Frontiers in Psychology

Received: 14 August 2020 Accepted: 16 October 2020 Published: 30 November 2020

Citation:

Pirchio S, Fraijo Sing BS and Passiatore Y (2020) Editorial: Where to Raise Happy and Skilled Children: How Environment Shapes Human

Development and Education.

Front. Psychol. 11:594924. doi: 10.3389/fpsyg.2020.594924 an adult, offering important insights into interventions, education, and social policies.

Following a basic assumption of environmental psychology, human beings, as all forms of living organisms, are shaped by the physical and social characteristics of their life's environments, impacting on the development of their skills, preferences, habits, and behaviors (Bonnes and Carrus, 2004; Mercado-Doménech et al., 2017). On the other hand, individuals and social groups leave a footprint on their habitats. The environment is, in some measure, an outcome of human actions (Gifford, 2011).

According to the ecological approach to human development (Bronfenbrenner, 1979), child development occurs in a series of hierarchically organized environmental systems, characterized by specific properties, components, and rules and linked by reciprocal and dynamic relations, and interactions. The social-relational aspects of development and the impact of specific activities for learning and acquisition represent the main research stream in this framework (e.g., Bruner, 1983; Tomasello et al., 1993; Pontecorvo and Pirchio, 2000).

Recently, however, psychologists have shifted their attention toward investigating the relationships among the physical properties of the environment and child development and behavior (Legendre, 2003; Evans, 2006; Carrus et al., 2015).

The articles included in this Research Topic contribute relevant knowledge about "where to raise happy and skilled children" from three different perspectives. In the first perspective, features of home and the school environment are juxtaposed with aspects of children's developmental processes, such as the development of gender stereotypes (Solbes-Canales et al.) and environmental attitudes and behaviors (Durón-Ramos et al.) and with developmental resources such as parental 
involvement in their children's education (Echeverría-Castro et al.). Rural and urban living environments are not only physically different, but foster and constrain the experiences adults and children could have in different ways, and may play a role in their happiness and well-being (Cerina and Fornara, 2011; Kabisch et al., 2017; Maricchiolo et al., 2020) through complex dynamics involving the environmental affordances and the people's behaviors and choices (Carrus et al., 2020). To be able to identify environmental features that play a role in children's development and behaviors certainly contributes to identifying and shaping positive educational environments (Tapia-Fonllem et al.).

A second perspective links six articles that shed light on the connectedness to nature and on the challenges and resources to improve the feeling of connection to nature in children in educational settings. Connectedness to nature is an important factor in environmental education as it is linked to proenvironmental behaviors (Liefländer et al., 2013). There is a robust tradition of environmental education trying to target connectedness to nature to have an impact on pro-environmental behavior (Passafaro et al., 2010; Otto and Pensini, 2017; VarelaCandamio et al., 2018), showing how complex it can be to create long-term effects in children's attitudes and behaviors toward nature and the environment. Although incomplete, preschool children already have a concept of nature (Fraijo-Sing et al.), and they attach their positive and negative emotional responses to nature (Olivos-Jara et al.); moreover, connectedness to nature is related to sustainable behaviors and happiness and related to the child's self-definition (Barrera-Hernández et al.). Given the relevance of the connection to nature for a child's wellbeing and for the environmental development, interventions aiming to increase connection to nature are important. The mini review by Barrable and Booth analyzes different types of interventions and identifies relevant variables to be considered for further research and for planning interventions, such as

\section{REFERENCES}

Bonnes, M., and Carrus, G. (2004). "Environmental psychology, overview," in Encyclopedia of Applied Psychology, Vol. 1, ed C. Spielberger (New York, NY: Academic Press-Elsevier), 801-814.

Bronfenbrenner, U. (1979). The Ecology of Human Development. Cambridge, MA: Harvard University Press.

Bruner, J. (1983). Child's Talk. Learning to Use Language. New York, NY: W.W. Norton.

Carrus, G., Passiatore, Y., Pirchio, S., and Scopelliti, M. (2015). Contact with nature in educational settings might help cognitive functioning and promote positive social behaviour/El contacto con la naturaleza en los contextos educativos podría mejorar el funcionamiento cognitivo y fomentar el comportamiento social positivo. Psyecology 6, 191-212. doi: 10.1080/21711976.2015.1026079

Carrus, G., Pirchio, S., and Tiberio, L. (2020). Transitions to sustainability, lifestyles changes and human well-being: cultural, environmental and political challenges ((Transiciones hacia la sostenibilidad, cambios de estilos de vida y bienestar humano: desafíos culturales, medioambientales y políticos)). Psyecology 11, 163-169. doi: 10.1080/21711976.2020.1734411

Carrus, G., Scopelliti, M., Panno, A., Lafortezza, R., Colangelo, G., Pirchio, S., et al. (2017). A different way to stay in touch with 'urban nature': the perceived restorative qualities of botanical gardens. Front. Psychol. 8:914. doi: 10.3389/fpsyg.2017.00914 the age of participants and length of the contact with nature. Even if there could be several settings in which connection to nature could be increased, educational institutions, and schools in particular, seem to be the most important. The articles by Pérez-López et al. and van Dijk-Wesselius et al., address the issue of providing preschool and primary school teachers with the knowledge, attitudes, and confidence to implement educational activities involving nature. The research within this perspective highlights the need for more systematic studies on the effect of diverse types of experiences with nature on environmental attitudes and pro-environmental behaviors.

The studies in the third perspective address the cognitive side of the research on the outcomes of contact with nature. Natural environments have a restorative power. Being in contact with nature recharges an individual's cognitive and emotional resources (Kaplan and Kaplan, 1989; Hartig, 2004) in adults (Hartig et al., 2011; Carrus et al., 2017) and children (Hattie et al., 1997; Korpela, 2002; Carrus et al., 2015). Johnson et al. find effects of a nature intervention on children's endogenous attention, and Federico discusses the convergent influence of the natural environment and of social relationships on stress reduction and, consequently, on attentional processes.

Our Research Topic contributes to the study of environmental psychology by accumulating new knowledge about the ways in which physical qualities of educational environments influence children's cognitive functioning and social behavior, assessing instruments to measure relevant factors of child development in different living environments, and in discussing environmental interventions.

\section{AUTHOR CONTRIBUTIONS}

All authors listed have made a substantial, direct and intellectual contribution to the work, and approved it for publication.

Cerina, V., and Fornara, F. (2011). The psychological determinants of attitudes toward relocation in the elderly: a survey study in urban and rural environments. Psyecology 2, 335-348. doi: 10.1174/217119711797 877744

Evans, G. W. (2006). Child development and the physical environment. Annu. Rev. Psychol. 57, 423-451. doi: 10.1146/annurev.psych.57.102904.190057

Gifford, R. (2011). The dragons of inaction: psychological barriers that limit climate change mitigation and adaptation. Am. Psychol. 66:290. doi: $10.1037 / \mathrm{a} 0023566$

Hartig, T. (2004). "Restorative environments," in Encyclopedia of Applied Psychology, ed C. Spielberger (New York, NY: Academic Press/Elsevier), 273-279.

Hartig, T., van den Berg, A. E., Hagerhall, C. M., Tomalak, M., Bauer, N., Hansmann, R., et al. (2011). "Health benefits of nature experience: psychological, social and cultural processes," in Forests, Trees and Human Health, eds K. Nilsson, M. Sangster, C. Gallis, T. Hartig, S. de Vries, K. Seeland, et al. (Berlin: Springer Science), 127-168.

Hattie, J., Marsh, H. W., Neill, J., and Richards, G. (1997). Adventure education and outward bound. Rev. Educ. Res. 67, 43-87. doi: 10.3102/00346543067001043

Hendry, L. B., and Kloep, M. (2002). Lifespan Development: Resources, Challenges and Risks. Boston, MA: Cengage Learning EMEA.

Kabisch, N., van den Bosch, M., and Lafortezza, R. (2017). The health benefits of nature-based solutions to urbanization challenges for children 
and the elderly-A systematic review. Environ. Res. 159, 362-373. doi: 10.1016/j.envres.2017.08.004

Kaplan, R., and Kaplan, S. (1989). The Experience of Nature: A Psychological Perspective. New York, NY: Cambridge University Press.

Korpela, K. (2002). “Children's environment,” in Environmental Psychology, eds R. B. Bechtel and A. Churchman (New York, NY: Wiley), 363-373.

Legendre, A. (2003). Environmental features influencing toddlers' bioemotional reactions in day care centers. Environ. Behav. 35, 523-549. doi: 10.1177/0013916503035004005

Liefländer, A. K., Fröhlich, G., Bogner, F. X., and Schultz, P. W. (2013). Promoting connectedness with nature through environmental education. Environ. Educ. Res. 19, 370-384. doi: 10.1080/13504622.2012.697545

Maricchiolo, F., Mosca, O., Lauriola, M., and Krys, K. (2020). The role of urbanization of place of living in the relation between individual features and happiness (El papel del desarrollo urbanístico del lugar de residencia en la relación entre las características individuales y la felicidad). Psyecology 11, 232-259. doi: 10.1080/21711976.2020.1734399

Mercado-Doménech, S. J., Carrus, G., Terán-Álvarez-Del-Rey, A., and Pirchio, S. (2017). Valuation theory: an environmental, developmental and evolutionary psychological approach. Implications for the field of environmental education. J. Educ. Cult. Psychol. Stud. 16, 77-97. doi: 10.7358/ecps-2017-016merc

Otto, S., and Pensini, P. (2017). Nature-based environmental education of children: environmental knowledge and connectedness to nature, together, are related to ecological behaviour. Global Environ. Change 47, 88-94. doi: 10.1016/j.gloenvcha.2017.09.009

Passafaro, P., Carrus, G., and Pirchio, S. (2010). I bambini e l'ecologia: gli aspetti psicologici dell'educazione ambientale. Rome: Carocci.

Pontecorvo, C., and Pirchio, S. (2000). A developmental view on children's arguing: the need of the other. Hum. Dev. 43, 361-363. doi: 10.1159/000022696

Tomasello, M., Kruger, A. C., and Ratner, H. H. (1993). Cultural learning. Behav. Brain Sci. 16, 495-511. doi: 10.1017/S0140525X0003123X

Varela-Candamio, L., Novo-Corti, I., and García-Álvarez, M. T. (2018). The importance of environmental education in the determinants of green behavior: a meta-analysis approach. J. Clean. Prod. 170, 1565-1578. doi: 10.1016/j.jclepro.2017.09.214

Conflict of Interest: The authors declare that the research was conducted in the absence of any commercial or financial relationships that could be construed as a potential conflict of interest.

Copyright (C) 2020 Pirchio, Fraijo Sing and Passiatore. This is an open-access article distributed under the terms of the Creative Commons Attribution License (CC BY). The use, distribution or reproduction in other forums is permitted, provided the original author(s) and the copyright owner(s) are credited and that the original publication in this journal is cited, in accordance with accepted academic practice. No use, distribution or reproduction is permitted which does not comply with these terms. 